\title{
DE NOVO DUPLICATION OF CHROMOSOME 7 (q21.1-q32); CASE REPORT AND REVIEW OF THE LITERATURE
}

\author{
Nasiri $F^{1}$, Mahjoubi $F^{1,2, *}$, Babamohammadi $G^{1}$
}

\begin{abstract}
*Corresponding Author: Frouzandeh Mahjoubi, The Blood Transfusion Organization Research Center (IBTO), Hemmat Exp.Way, Next to Milad Tower, Tehran, Iran; P.O. Box 14665-1157; Tel.: +9821-88601501-30; Fax:+9821-88601555; E-mail:Frouz@nigeb.ac.ir
\end{abstract}

\begin{abstract}
Cytogenetic analysis of a 1-year-old boy with multiple congenital anomalies revealed partial duplication of the chromosome 7q21.2-q32 band region. His main features included: frontal bossing, small jaw, low-set ears, deep-set eyes, strabismus, drooping left upper eyelid, widely-spaced eyes, short nose, long philtrum, down-curved upper lip, camptodactyly and hypotonia.
\end{abstract}

Key words: Partial duplication of chromosome $7 \mathrm{q}$

\section{INTRODUCTION}

Partial trisomy/duplication of chromosome 7q is associated with a characteristic syndrome of frontal bossing, retrognathia, small jaw, low-set ears, dysplastic ears, deep-set and prominent eyes, strabismus, down-curved upper lip, small mouth, short hands, stiffness of fingers and other joints, joint laxity, scoliosis, reduced muscle tone, hydrocephalus, growth retardation, strabismus, coloboma of iris,

The Blood Transfusion Organization Research Center, Tehran, Iran

2 Clinical Genetics Department, National Institute of Genetic Engineering and Biotechnology (NIGEB), Tehran, Iran drooping upper eyelid, widely-spaced eyes, long eyelashes and short space between eyelids [1-8].

\section{CASE REPORT}

A 1-year -old boy was referred to our clinic because of developmental delay. He was the fourth offspring of an unrelated healthy couple and his siblings had no significant health problems. He was born by natural delivery after a full term pregnancy weighing 1,500 gr and head circumstance within the normal range. At examination he had frontal bossing, small jaw, low-set ears, deep-set eyes, strabismus, drooping left upper eyelid, widely-spaced eyes, short nose, long philtrum, down-curved upper lip, camptodactyly, hypotonia, and macrocephaly (Figure 1). He had severe psychomotor retardation, failure to thrive, and poor interaction with the environment.

Cytogenetic analysis of phytohemagglutinin (PHA) stimulated peripheral blood sample was performed and showed additional material on the long arm of chromosome 7 (Figure 2). Chromosomal analysis of both parents revealed normal karyotypes. High resolution chromosomal analysis of the proband showed 46,XY,dup 7(q21.2-q32). Twelve patients with duplication/trisomy of $7 \mathrm{q}$ have been reported [1-8]. A summary of clinical findings of patients with partial duplication of $7 \mathrm{q}$ is given in Table 1 . 


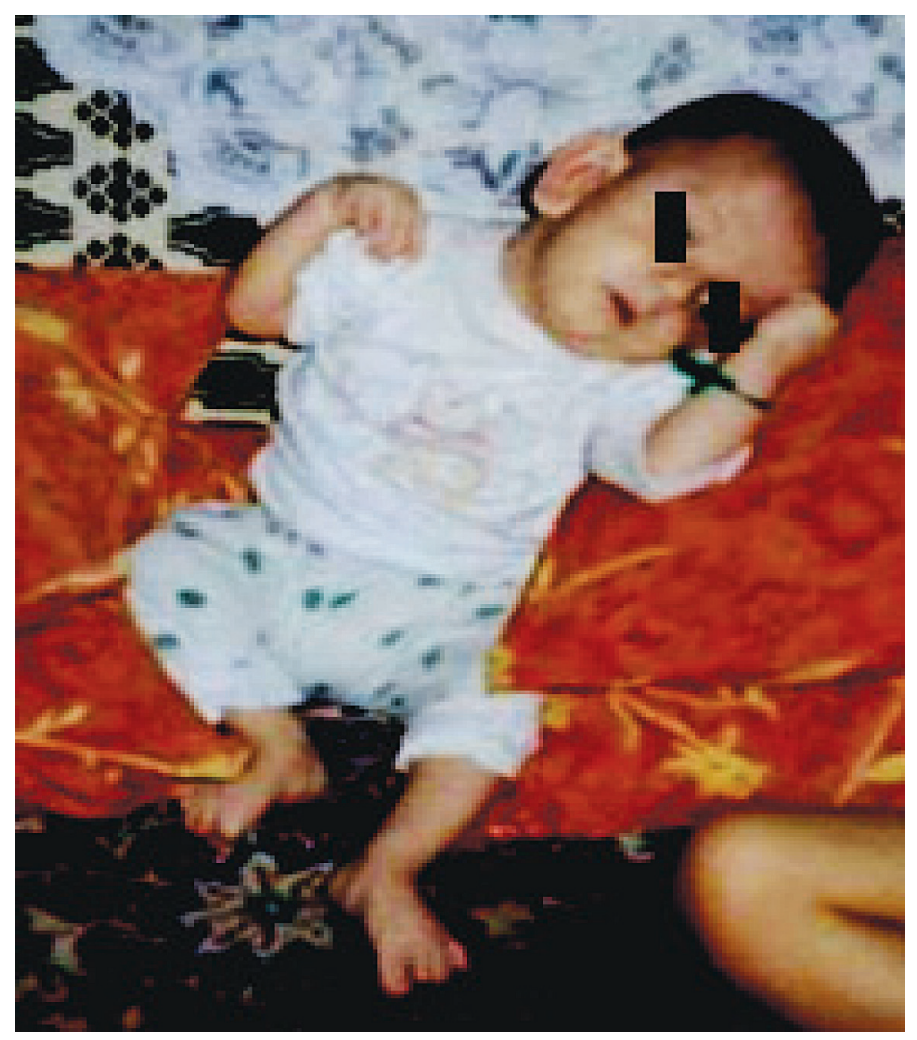

Figure 1. Photograph showing the patient at 12 months of age. explain the great clinical variability between reported patients as has been emphasized by Morales et al [9].

To the best of our knowledge, our patient is the first reported case of a duplicated $7 \mathrm{q}$ for the region between $7 \mathrm{q} 21.2$ and $7 \mathrm{q} 32$. We suggest that the $7 \mathrm{q} 21.2$ region may be critical for the macrocephaly with frontal bossing in our patient and in the patient of Lukusa et al. [4].

\section{ACKNOWLEDGMENTS}

The authors would like to acknowledge the cooperation of the proband's family. This study was done at the Cytogenetic Department, The Blood Transfusion Organization, Tehran, Iran.

\section{REFERENCES}

1. Scelsa B, Bedeschi FM, Guerneri S, Lalatta F, Introvini P. Partial Trisomy of 7q: case report and literature review. J Child Neurol 2008; 23(5): 572-579.

2. Couzin DA, Haites N, Watt JL, Johnston AW. Partial trisomy 7 (q32-qter) syndrome in two children. J Med Genet 1986; 23(5): 461-465.

3. Lukusa T, Fryns JP. Syndrome of facial, oral, and digital anomalies due to $7 \mathrm{q} 21.2 \rightarrow \mathrm{q} 22.1$ duplication. Am J Med Genet 1998; 80(5): 454-458.

4. Lukusa T, Van Buggenhout G, Devriendt of the existence of andetectable cell line in patients with pure partial $7 \mathrm{q}$ trisomy or monosomy to

Table.1. A summary of clinical findings of patients with partial duplication of 7q.

\begin{tabular}{|l|l|c|}
\hline Region & \multicolumn{1}{|c|}{ Clinical Findings } & Reference \\
\hline 7q21.2-q22.1 & $\begin{array}{l}\text { Mental retardation; macrocephaly; frontal bossing; hyperterlorism; } \\
\text { small palpebral fissures with downward slant; lobulated tongue; multiple } \\
\text { intrabuccal frenula; oligdontia and enamel hypoplasia; cutaneous } \\
\text { syndactlyly of fingers 2,3 and 3,4; broad and short fingertips and fetal pads; } \\
\text { broad thumbs; halluces }\end{array}$ & 3 \\
\hline 7q21qter & $\begin{array}{l}\text { Cleft palate; cerebellar hypoplasia and anomalies of the pancreas, gall } \\
\text { bladder and appendix }\end{array}$ & 7 \\
\hline 7q22.1q31.2 & $\begin{array}{l}\text { Mental retardation; strabismus; low-set ears; depressed nasal bridge; small } \\
\text { nose; hypotonia }\end{array}$ & 5 \\
\hline 7q31.3qter & $\begin{array}{l}\text { Skeletal abnormalities; facial dysmorphism; dilated cerebral ventricles; } \\
\text { microretrognathia and short neck }\end{array}$ & 6 \\
\hline 7q35-qter & Developmental and mental retardation; abnormal ears; kyphosis & 4 \\
\hline 7q35qter & Cleft palate; severe hypotonia and joint contractures & 8 \\
\hline
\end{tabular}


A)

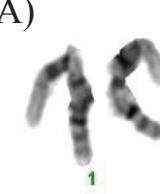

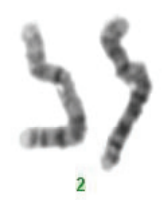
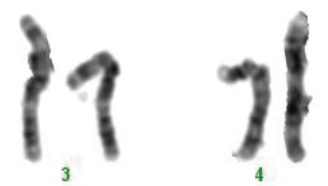

!I

Ms!

$\pi$

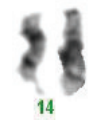

$3 e$
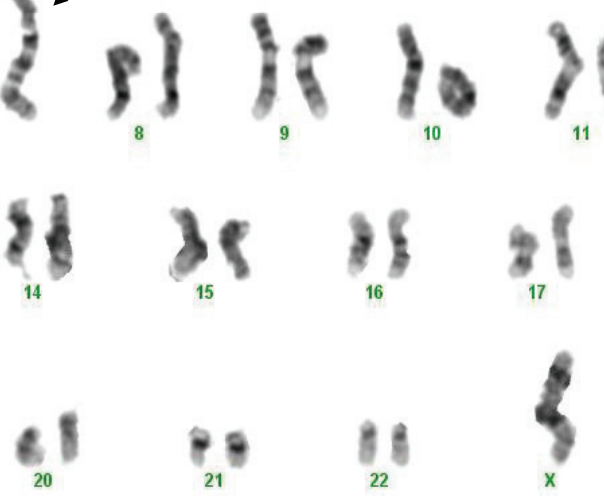
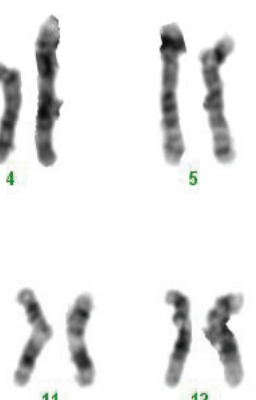

B)
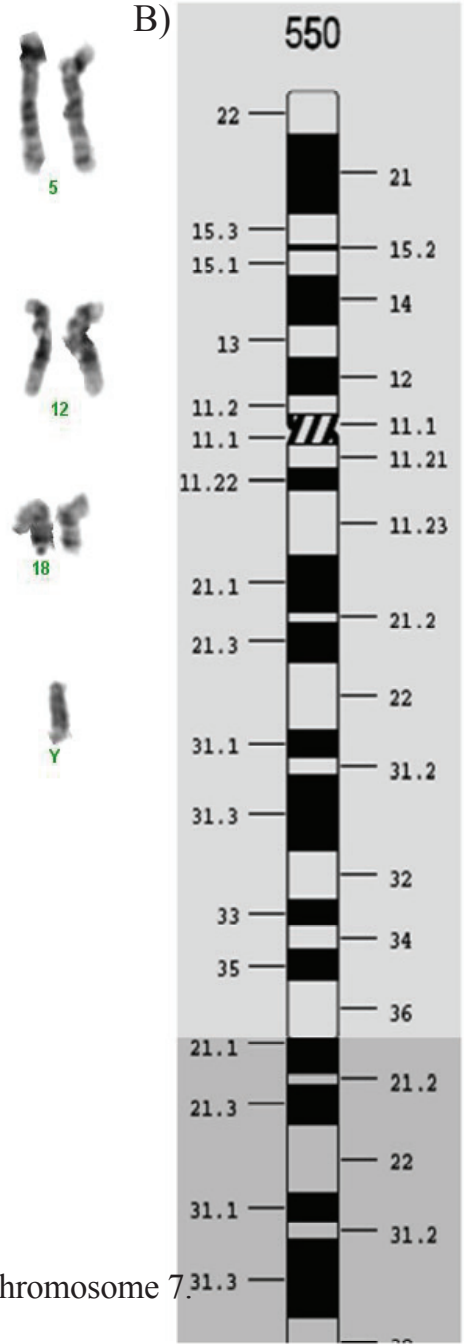

Figure 2. A) Karyotype of patient. Arrow shows the abnormal chromosome 7.31 .3
B) Abnormal chromosome 7 .

7. Courtens W, Vroman S, Vandenhove J, Wie-

K, Fryns JP. Pericentric inversion with partial 7(q35 $\rightarrow$ qter) duplication and 7pter deletion: diagnosis by cytogenetic and fish analysis in a 29 -yearold male patient. Genet Couns. 2002; 13(1): 1-10.

5. Romain DR, Cairney H, Stewart D, Columbano-Green LM, Garry M, Parslow MI, Parfitt R, Smythe RH, Chapman CJ. Three cases of partial trisomy $7 \mathrm{q}$ owing to rare structural rearrangements of chromosome 7. J Med Genet 1990; 27(2): 109-113.

6. Goodman BK, Stone K, Coddett JM, Cargile CB, Gurewitsch ED, Blakemore KJ, Stetten G. Molecular cytogenetic analysis and clinical findings in a newborn with prenatally diagnosed $\operatorname{rec}(7) \operatorname{dup}(7 \mathrm{q})$ inv(7)(p22q31.3)pat. Prenat Diagn 1999; 19(12): 1150-1156. emann U, Schinzel A. Pre- and perinatal findings in partial trisomy $7 q$ resulting from balanced parental translocations $\mathrm{t}(7 ; 21)$ and $\mathrm{t}(4 ; 7)$. Prenat Diagn 2001; 21(8): 642-648.

8. Morava E, Bartsch O, Czakó M, Frensel A, Kalscheuer V, Kárteszi J, Kosztolányi G. Small inherited terminal duplication of $7 \mathrm{q}$ with hydrocephalus, cleft palate, joint contractures, and severe hypotonia. Clin Dysmorphol 2003; 12(2): 123-127.

9. Morales C, Madrigal I, Esqué T, de la Fuente JE, Rodríguez JM, Margarit E, Soler A, Sánchez A. Duplication/deletion mosaicism of the $7 \mathrm{q}(21.1 \rightarrow 31.3)$ region. Am J Med Genet A 2007; 143(2): 179-183. 
